\author{
Serhiy Pyshyev ${ }^{1}$, Yuriy Grytsenko ${ }^{1}$, Serhiy Solodkyy ${ }^{2}$, Iurii Sidun ${ }^{2}$ \\ and Oleksiy Vollis ${ }^{2}$
}

\title{
USING BITUMEN EMULSIONS BASED ON OXIDATED, DISTILLATION AND MODIFIED OXIDATED BITUMENS FOR SLURRY SEAL PRODUCTION
}

\author{
1Institute of Chemistry and Chemical Technology, \\ Lviv Polytecnic National University, 12, S. Bandery str., 79013 Lviv, Ukraine \\ Institute of Building and Environmental Engineering, \\ Lviv Polytecnic N ational University, St. Bandery 12, 79013 Lviv, Ukraine
}

Received: December 12, 2014 / Revised: December 25, 2014 / Accepted: April 03, 2015

C Pyshyev S., Grytsenko Y., Solodkyy S., Sidun IU., Vollis O., 2015

\begin{abstract}
Three commercial road emulsions on the basis of petroleum bitumens differing by their production method (oxidated, distillation and modified bitumens) and Redicote E-11 emulsifier were obtained. The obtained emulsions were used for the production of Slurry Seal and thin-layer road coatings on its basis. The coatings based on modified oxidated bitumen have more advantages compared with those based on oxidated bitumen. The expensive distillation bitumen may be exchanged for modified oxidative one to use it in a Slurry Seal technology. We propose to use the indene-coumarone resin for oxidated bitumen modification to improve its adhesive and cohesive properties.
\end{abstract}

Keywords: slurry seal, thin-layer coating, bitumen, bitumen emulsion, modifier, indene-coumarone resin.

\section{Introduction}

Every year the load on the road coatings increases due to the increase in number and tonnage of vehicles. The logical result is the increase in intensity and velocity of roadways destruction.

Production of thin-layer coatings (TLC) from Slurry Seal is one of the modern technologies allowing to solve the problem of protecting the roadway upper layers and fast recovery of their operational properties Slurry Seal is obtained via mixing macadam (with the particles size of less than $15 \mathrm{~mm}$ ) or undersized crushed-stone, bitumen emulsion (BE), water, mineral filler, and regulator of emulsion lability at the ambient temperature not below $298 \mathrm{~K}$. The main aim of the process of TLC production from Slurry Seal is extension of the service life of the existing coatings by cracks and small pot-holes pouring, considerable increase of roughness and adhesive properties, improvement of coating evenness, prevention of crack formation, protection from water saturation, and rebuilding of worn or preservation of the existing coating upper layer [1-3]. While using bitumen emulsions and Slurry Seal there are a lot of advantages compared with hot asphalt concrete technologies [4]:

- decrease of deleterious effect on the environment;

- lower power-consuming of the technological process due to the absence of drying, heating of stone materials and bitumen, maintaining of high temperature while stirring;

- combination of Slurry Seal preparing and laying in the same machine during its motion along the road;

- prolongation of the season for building due to the possible works at the temperatures of $278 \mathrm{~K}$ and higher;

possibility to work with wet coatings.

To produce the high-quality Slurry Seal the expensive and deficit distillation bitumen is usually used. The mixtures produced according to Slurry Seal technology are obtained from oxidated petroleum bitumen with poor adhesive and cohesive properties. Inadequate adhesive properties lead to the destruction of TLC produced on its basis; low speed of required strength gain causes impossibility of fast recovery of vehicular traffic after the works.

One of the ways of improving the operational properties of the oxidated petroleum bitumen is its modification by adhesive, polymeric and cross-linking additives [5]. To produce bitumen modified by polymers (BMP) a series of modifiers is used, in particular Elvaloy 
4170 (DuPont company), which is a copolymer of ethylene with butylacrylate and glycidylmethacrylate [6], thermoelastoplasts of styrene-butadiene-styrene type Kraton D (Kraton Polimers company), synthetic latexes of Butonal NS type (BASF company) [7, 8], etc. However, in Ukraine the share of modified bitumen used in the road building is only $1-5 \%$. The reason is high cost of the modifiers.

The analysis of literature data [9] confirms that indene-coumarone resin (ICR) has high adhesive and emulsifying properties. This suggests that ICR can be used as a modifier for bitumen and bitumen emulsions. ICR is a copolymer of indene, coumarone, styrene and their derivatives; its cost is considerably lower than that of the above-mentioned modifiers [10]. Data represented in Ref. $[11,12]$ prove the possibility of ICR using as a modifier for bitumen modification with the aim of increasing its softening temperature and adhesion to mineral materials.

The raw material for ICR production is one of byproducts of coke production - indene-coumarone fraction (ICF) often called as "heavy benzene" [13]. ICF is a distillation product of gasoline fractions which are obtained, in their turn, via thermal destruction of coal organic matter during its coking. Nowadays indenecoumarone resins are not produced in Ukraine. The reason is that the main consumer (lacquer-paint industry) changed the resins for cheaper and more effective components. Therefore, application of ICR for bitumen modification not only improves the operational properties but allows to use the by-product (ICF) of coke production.

There are several industrial ICRs differing by softening temperature $\left(T_{s}\right)$ [14]. It is logically to use resins with high $T_{s}$ to decrease the modifier amount necessary to achieve the required softening temperature of BMP. On the other hand, it is unknown how the change of $T_{s}$ will affect the adhesion properties of the modified bitumen.
Thus the aims of this work are:

- study of the effect of ICR softening temperature on the adhesive properties of the modified bitumen;

- obtaining of bitumen and bitumen emulsion modified by ICR;

- comparison of properties of bitumen emulsions based on modified bitumen with those based on nonmodified oxidative and residual (distillation) bitumen;

- application of bitumen emulsions (including those modified by ICR) for Slurry Seal production.

\section{Experimental}

\subsection{Initial Materials}

The fraction $413-463 \mathrm{~K}$ was used as a raw material for ICR production. The fraction is obtained from wide ICF fraction withdrawn at JSC "Yasynovsky coke plant" (Donetsk, Ukraine). $\mathrm{TiCl}_{4}$ was used as a catalyst. The characteristics of raw material are represented in Table 1.

To obtain BMP and BE we used: viscous oxidated road bitumen BND 60/90 withdrawn at JSC "Ukrtatnafta" (Kremenchuk, Ukraine); distillation bitumen Nynas 70100 (Nynas company, Sweden); emulsifier Redicote E-11 (Akzo Nobel, Sweden). The official distributor of the latter two components is "Prologue TD" Ltd company (Lviv, Ukraine). The characteristics of bitumens are represented in Tables 2 and 3.

To obtain Slurry Seal we used: fraction $0-10 \mathrm{~mm}$ of granite scree (JSC "Tomashgorsky scree plant, Tomashgorod, Ukraine); portlandcement PC II/A-Sh-400 (JSC “Mykolaivcement”, Mykolaiv, Ukraine); regulating additive $-10 \%$ aqueous solution of Redicote E- 11 .

Table 1

Characteristics of indene-coumarone fraction boiled within 413-463 K

\begin{tabular}{|c|c|c|c|}
\hline Temperature, $\mathrm{K}$ & $\begin{array}{c}\text { Yield of the fraction } 413-463 \mathrm{~K}, \\
\text { wt } \%\end{array}$ & $\begin{array}{c}\text { Bromine number, } \\
\mathrm{g} \mathrm{Br}_{2} / 100 \mathrm{~g} \text { product }\end{array}$ & $\begin{array}{c}\text { Content of unsaturated } \\
\text { compounds, wt } \%\end{array}$ \\
\hline 412 & 0.0 & & \\
413 & 10.0 & & \\
413 & 20.0 & & \\
415 & 30.0 & & \\
419 & 40.0 & & \\
423 & 50.0 & & \\
428 & 60.0 & \\
433 & 70.0 & & \\
441 & 80.0 & & \\
473 & 90.0 & & \\
\end{tabular}

${ }^{1}$ Average molecular mass of unsaturated compounds present in the fraction $413-463 \mathrm{~K}$ is equal to 138 
Table 2

\section{Characteristics of road bitumen BND 60/90}

\begin{tabular}{|l|c|c|}
\hline \multicolumn{1}{|c|}{ Index } & Actual value & $\begin{array}{c}\text { Standard according to } \\
\text { DSTU 4044-2001 [15] }\end{array}$ \\
\hline Penetration at 298 K $\left(\mathrm{m} \cdot 10^{-4}\right)$ & 72 & $61-90$ \\
\hline Softening temperature (ball \& ring method), K & 322 & $320-326$ \\
\hline $\begin{array}{l}\text { Ductility, } \mathrm{M} \cdot 10^{-2}(\mathrm{~cm}) \\
\text { at 273K }\end{array}$ & 3 & $\geq 3$ \\
at 298 K & 84 & $\geq 55$ \\
\hline Change of properties after heating: & & \\
\cline { 1 - 1 } Change of weight after heating, \% & 0.12 & $\leq 0.8$ \\
\cline { 1 - 1 } Residual penetration, \% & 72 & $\geq 60$ \\
\cline { 1 - 2 } Change of softening temperature, K & 4 & $\leq 6$ \\
\hline Fraaß breaking point, K & 255 & $\leq 255$ \\
\hline Flash point determined in open firepot, K & 557 & Not standardized \\
\hline Adhesion to glass, \% & 32 & Not standardized \\
\hline Low-temperature adhesion, \% & 28 & Not standardized \\
\hline Mass part of paraffins, \% & 8.0 & $\geq 99.00$ \\
\hline Solubility in organic solvents, \% & 99.5 & $-2.0 \pm 1.0$ \\
\hline Penetration index & -0.6 & \\
\hline
\end{tabular}

Table 3

\section{Characteristics of road bitumen Nynas 70/100}

\begin{tabular}{|c|c|c|}
\hline Index & Actual value & $\begin{array}{c}\text { Standard according to EN } \\
12591-2009[16]\end{array}$ \\
\hline Penetration at $298 \mathrm{~K}\left(\mathrm{~m} \cdot 10^{-4}\right)$ & 85 & $61-90$ \\
\hline Softening temperature (ball \& ring method), $\mathrm{K}$ & 321 & $320-326$ \\
\hline Change of properties after heating: & \multirow{4}{*}{$\begin{array}{c}0.8 \\
46 \\
4\end{array}$} & \multirow{4}{*}{$\begin{array}{l}\leq 0.8 \\
\geq 46 \\
\leq 6\end{array}$} \\
\hline Change of weight after heating, \% & & \\
\hline Residual penetration, $\%$ & & \\
\hline Change of softening temperature, $\mathrm{K}$ & & \\
\hline Fraaß breaking point, $\mathrm{K}$ & 262 & $253-263$ \\
\hline Flash point determined in open firepot, $\mathrm{K}$ & 505 & $\geq 503$ \\
\hline Solubility in organic solvents, $\%$ & 99.4 & $\geq 99.00$ \\
\hline Density at $298 \mathrm{~K}, \mathrm{~g} / \mathrm{cm}^{3}$ & 1.06 & $1.0-1.07$ \\
\hline Kinematic viscosity at $408 \mathrm{~K}, \mathrm{~mm}^{2} / \mathrm{s}$ & 231 & $\geq 230$ \\
\hline
\end{tabular}

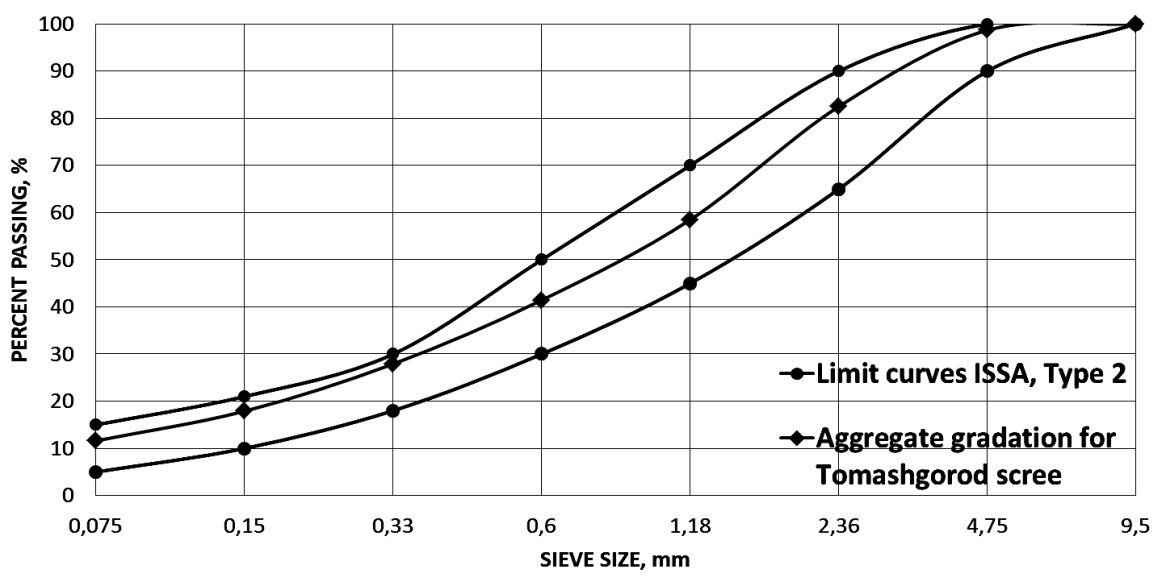

Fig. 1. Grain-size composition of Tomashgorod scree according to ISSA 


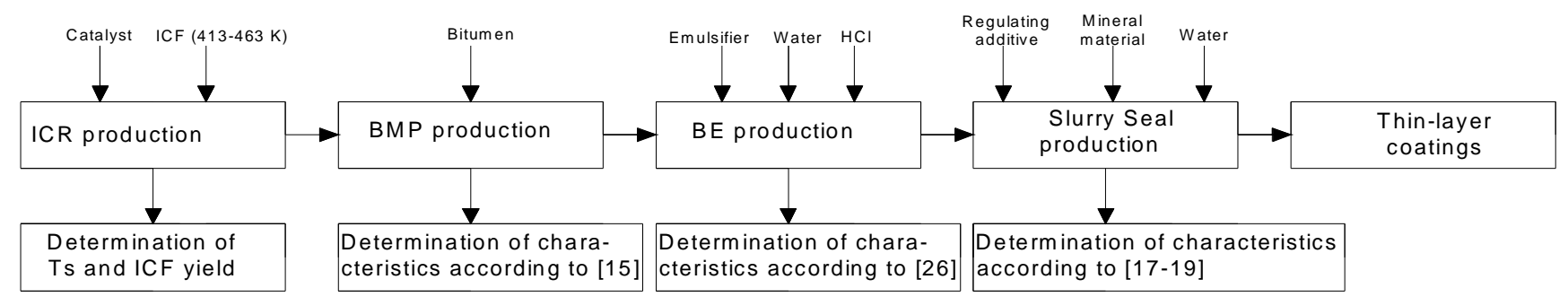

Fig. 2. Scheme of experimental investigations

According to its grain-size composition (Fig. 1) the granite scree refers to the type 2 (International Slurry Surfacing Association, ISSA) [17] and may be used for Slurry Seal production. Slurry Seal based on this filler is recommended to be used for the urban and local roads, as well as for aerodrome landing strips.

\subsection{Experimental Procedure}

The obtaining of modifier (ICR), bitumen modification by it, preparation of emulsions and slurry seal, as well as their use for TLC production were conducted according to the Scheme given in Fig. 2.

\subsubsection{ICR production}

ICF is pretreated before the cooligomerization: it is dried and pyridine bases are removed using $72 \%$ sulphuric acid. Such pretreatment allows to decrease the catalyst amount and increase ICR yield and softening temperature. The prepared raw material is loaded into a reactor, then the process conditions (time, temperature, catalyst amount) are set and oligomerization is carried out under constant stirring. The obtained product is washed by water till the reaction becomes neutral. The unreacted raw material is purified from ICR using vacuum distillation.

\subsubsection{BM P production}

BMP is prepared as follows: necessary amount of bitumen is heated to the given temperature, then modifier is added and stirring is turned on $(R e=1200)$. The modification time is $1 \mathrm{~h}$, the modification temperatures are given in [11]. The amount of polymer is determined by the experiments based on the need to obtain BMP with $T_{s}=325-327 \mathrm{~K}$.

\subsubsection{BE production}

Bitumen emulsions are prepared as follows:

- "aqueous phase" preparation;

- "bitumen phase" preparation;

- two phases mixing by means of laboratory bitumen-emulsion plant SEP-0.3R (Denimotex company, Denmark).
Aqueous and bitumen phases are loaded into the special vessels of the plant, then they are heated till given temperature (aqueous phase - $343 \mathrm{~K}$, bitumen phase $413 \mathrm{~K}$ ) and bitumen emulsion is produced by mixing in colloid mill.

To calculate the components amount in the emulsion we used computer program appended to the plant.

\subsubsection{TLC production from Slurry Seal}

Slurry Seal is prepared and tested according to ISSA requirements [17, 18] and EN standard [19] at $298 \mathrm{~K}$ and air relative humidity of $77 \%$. Slurry Seal composition is designed to achieve necessary time of its break (time from all component mixing till the moment the mixture loses its mobility and possibility of further mixing). This criterion determines the time during which the mixture should be prepared and layered. The general procedure for Slurry Seal break is as follows:

- mixing of mineral components, water, regulating additive and bitumen emulsion in the enamel ware;

- manual mixing of the obtained mixture by means of spatula in the tilted enamel vessel to evaluate the mixture mobility during all experiment time;

- fixing of mixture break.

The content of all components, when mixture break continues not less than $180 \mathrm{~s}$ is considered to be the optimum one.

TLC model is prepared by filling forming rings with the mixture. The ring diameter is $60 \mathrm{~mm}$, height is $10 \mathrm{~mm}$ and it is situated on the plate made of ruberoid. When the mixture loses mobility and fluidity, the samples are delivered from the rings and tested according to [18, 19] after definite periods of time. Each sample is classified according to the destruction character and corresponding torque value $\left(M_{0}\right)$. Ultimate shear strength is calculated according to formula (1):

$$
\tau=\frac{16 \cdot M_{0}}{\pi \cdot d^{3}}=0.21 \cdot M_{0}
$$


where $\tau$ - ultimate shear strength, MPa; $M_{0}-$ torque, $\mathrm{H} \cdot \mathrm{m}$; $d$ - diameter of rubber point equal to $29 \cdot 10^{-3} \mathrm{~m}$.

According to the standards $[17,18]$ such characteristics of Slurry Seal speed of cohesive strength gain as destruction character, torque values and ultimate shear strength must comply with the values represented in the Table 4.

\subsection{Analysis of Raw Material and Products}

The raw material, resin, bitumen and bitumen emulsions were analyzed according to the standard methods [20-23].

The essence of the method described in [24] is to determine bitumen adhesive properties while adhesion to glass after several freezing-unfreezing cycles. The freezing is carried out at $258 \mathrm{~K}$, unfreezing - at $298 \mathrm{~K}$ for $12 \mathrm{~h}$. Adhesion to glass is determined after samples are taken off the refrigerator. The investigation scheme is as follows:

- preparation of necessary numbers of samples;

- determination of adhesive properties of the initial samples;

- determination of adhesive properties after one freezing-unfreezing cycle;

- determination of adhesive properties after four freezing-unfreezing cycles;

- determination of adhesive properties after four freezing-unfreezing cycles followed by maintaining at $258 \mathrm{~K}$ for 4 days;
The value of low-temperature adhesion is calculated according to the formula (2):

$$
A_{-15}=\frac{1}{2}\left(\frac{A_{1}+A_{2}+A_{3}}{3}+A_{4}\right)
$$

where $A_{-15}$ - low-temperature adhesion (adhesion to glass at $258 \mathrm{~K}), \% ; A_{1}$ - initial value of adhesion to glass, \%; $A_{2}$ - adhesion to glass after one cycle, $\% ; A_{3}$ - adhesion to glass after four cycles, $\% ; A_{4}$ - adhesion to glass after four cycles and four days of maintaining, $\%$.

The filler for Slurry Seal (granite scree) is analyzed according to ISSA standards [17].

\section{Results and Discussion}

\subsection{BE Production}

As it was mentioned above, the softening temperature of bitumen modifiers may affect bitumen adhesive properties. According to the procedures described in Subsection 2.2.1 and Ref. [12, 25] we obtained ICR with different softening temperatures (Table 5).

The obtained results allow to assert that ICR addition to BND 60/90 road bitumen increases its softening temperature and significantly improves its adhesive properties (Fig. 3, Table 2). The increase in the softening temperature of the initial ICR leads to the improvement of BMP adhesive properties, including those at low temperatures. To prepare BMP with good adhesive properties (around 100\%) it is necessary to use ICR with $T_{s} \geq 403-413 \mathrm{~K}$.

Table 4

Requirements for the speed of cohesive strength gain of slurry seal

\begin{tabular}{|c|c|c|c|c|}
\hline \multirow{2}{*}{$\begin{array}{c}\text { Time to achieve } \\
\text { necessary cohesive } \\
\text { strength, } \mathrm{h}\end{array}$} & $\begin{array}{c}\text { Destruction } \\
\text { character }\end{array}$ & $\begin{array}{c}\text { Torque }\left(M_{0}\right), \\
\mathrm{H} \cdot \mathrm{m}\end{array}$ & $\begin{array}{c}\text { Ultimate shear } \\
\text { strength }(\tau), \mathrm{MPa}, \\
\text { not less than }\end{array}$ & Stages of Slurry Seal formation \\
\hline At the latest 0.5 & $\mathrm{~N}-$ Normal & $1.2-1.3$ & 0.25 & Setting \\
\hline At the latest 1 & $\mathrm{NS}-$ Normal Spin & $2.0-2.1$ & 0.42 & $\begin{array}{c}\text { Self-consolidation (opening of traffic } \\
\text { with a speed limit of } 40 \mathrm{~km} / \mathrm{h})\end{array}$ \\
\hline Not standardized & S - Spin & 2.3 & 0.48 & Consolidation \\
\hline Not standardized & $\mathrm{SS}-$ Solid Spin & 2.6 & 0.54 & Cured (opening of traffic without \\
speed limit)
\end{tabular}

Table 5

Conditions for ICR obtaining and its softening temperatures

\begin{tabular}{|c|c|c|c|}
\hline \multicolumn{2}{|c|}{ Conditions for ICF cooligomerization } & \multirow{2}{*}{$\begin{array}{c}\text { ICR softening temperature } \\
\text { according to B\&R method, } \mathrm{K}\end{array}$} \\
\hline Catalyst content, wt \% & Temperature, K & Time, min. & 370 \\
\hline 3 & 333 & 40 & 393 \\
\hline 3 & 313 & 80 & 401 \\
\hline 3 & 293 & 5 & 408 \\
\hline 3 & 293 & 80 & 413 \\
\hline
\end{tabular}




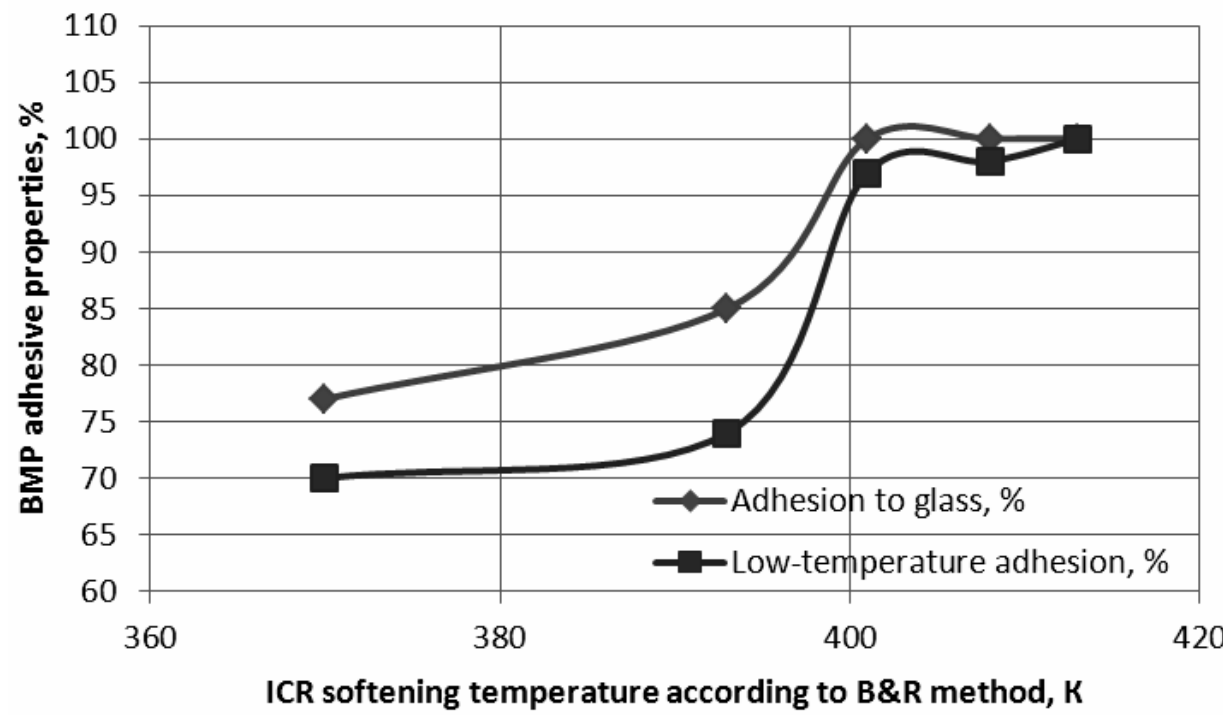

Fig. 3. BMP adhesive properties vs. ICR softening temperature

Table 6

Compositions of bitumen emulsions

\begin{tabular}{|l|c|c|c|}
\hline \multirow{2}{*}{ Emulsion components } & \multicolumn{2}{c|}{ Content of components in the emulsion, wt \% } \\
\cline { 2 - 4 } & BE 1 & BE 2 & BE 3 \\
\hline Bitumen & 62 & 62 & 62 \\
\hline Redicote E-11 emulsifier & 1.1 & 1.1 & 1.1 \\
\hline \multirow{2}{*}{ Hydrochloric acid } & $\begin{array}{c}\text { till } \mathrm{pH}=2.5 \text { in aqueous } \\
\text { phase }\end{array}$ & $\begin{array}{c}\text { till } \mathrm{pH}=2.5 \text { in aqueous } \\
\text { phase }\end{array}$ & $\begin{array}{c}\text { till } \mathrm{pH}=2.5 \text { in aqueous } \\
\text { phase }\end{array}$ \\
\hline Water & till 100 & till 100 & till 100 \\
\hline
\end{tabular}

Table 7

Physico-technical indices of bitumen emulsions

\begin{tabular}{|c|c|c|c|c|c|}
\hline \multirow[t]{2}{*}{ Index } & \multicolumn{2}{|c|}{$\begin{array}{l}\text { Requirements according to } \\
{[26]}\end{array}$} & \multicolumn{3}{|c|}{$\mathrm{BE}$} \\
\hline & ECS-60 & ECSM-60 & 1 & 2 & 3 \\
\hline Appearance & \multicolumn{2}{|c|}{$\begin{array}{l}\text { Homogeneous dark-brown } \\
\text { liquid }\end{array}$} & \multicolumn{3}{|c|}{ Fits the requirements } \\
\hline Hydrogen ions concentration, $\mathrm{pH}$ & \multicolumn{2}{|c|}{$1.5-6.5$} & 3.1 & 2.6 & 4.1 \\
\hline Homogeneity (sieve No.014 residue), $\%$, at most & 0.25 & 0.3 & 0.06 & 0.09 & 0.07 \\
\hline Content of residual binding agent & \multicolumn{2}{|c|}{$58-62$} & 61 & 61 & 61 \\
\hline $\begin{array}{l}\text { Assumed viscosity at } 293 \mathrm{~K} \text { (apparatus with hole diameter } \\
\text { of } 4 \mathrm{~mm}), \mathrm{s}\end{array}$ & \multicolumn{2}{|c|}{$5-25$} & 10 & 9 & 8.4 \\
\hline $\begin{array}{l}\text { Stability during storage: sieve No.014 residue, \%, at most } \\
\text { - after } 7 \text { days } \\
\text { - after } 30 \text { days }\end{array}$ & $\begin{array}{l}0.3 \\
0.4\end{array}$ & $\begin{array}{l}0.4 \\
0.5\end{array}$ & $\begin{array}{l}0.12 \\
0.21\end{array}$ & $\begin{array}{l}0.13 \\
0.23\end{array}$ & $\begin{array}{l}0.11 \\
0.19 \\
\end{array}$ \\
\hline $\begin{array}{l}\text { Adhesion of residual binding agent to macadam, points, no } \\
\text { less }\end{array}$ & \multicolumn{2}{|c|}{5.0} & 5.0 & 5.0 & 5.0 \\
\hline \multirow{2}{*}{$\begin{array}{l}\text { Miscibility with mixtures of grained } \\
\text { composition }\end{array}$} & \multicolumn{2}{|c|}{ Yes } & Yes & Yes & Yes \\
\hline & \multicolumn{2}{|c|}{ Yes } & Yes & Yes & Yes \\
\hline
\end{tabular}


To find the conditions for ICF cooligomerization, under which ICR maximum yield would be achieved $\left(T_{s} \geq 403 \mathrm{~K}\right)$ we developed experimental statistical mathematical model (ESM) of this process [25]. On the basis of regression equations, which describe this model, by means of uniform search technique we found the optimum conditions for ICR obtaining (temperature $310 \mathrm{~K}$, time $40 \mathrm{~min}$., catalyst concentration $3.3 \mathrm{wt} \%$ ). The resin yield is $33.3 \mathrm{wt} \%$ relative to the raw material and its $T_{s}$ is $408 \mathrm{~K}$.

The obtained ICR and BND 60/90 bitumen were used to prepare BMP (bitumen content is $93.3 \%$, ICR content - 6.7 wt \%). The BMP characteristics are: softening temperature according to $\mathrm{B} \& \mathrm{R}$ method is $325 \mathrm{~K}$, adhesion to glass $-100 \%$, low-temperature adhesion $97 \%$. According to the mentioned indexes the modified bitumen corresponds to BMP 60/90-52.

The oxidated initial and modified bitumens as well as distillation bitumen were used to produce bitumen emulsions:

- BE 1 - on the basis of BND 60/90 bitumen;
- BE 2 - on the basis of BMP 60/90-52 modified bitumen;

- BE 3 - on the basis of Nynas 70/100 bitumen.

BE compositions are represented in Table 6 and their physico-technical indices - in Table 7.

On the basis of represented results we can assert that obtained BE fit the normative documents. Thus, BE 1 and BE 3 correspond to ECS-60 type (cationic slowbreaking emulsion) and BE 2 - to ECSM-60 type (cationic slow-breaking modified emulsion).

\subsection{Determination of Slurry Seal Optimum Composition and Speed of Cohesive Strength Gain}

The obtained bitumen emulsions were used for the production of Slurry Seal together with other components. The optimum compositions of Slurry Seal according to the break criterion are represented in Table 8.

On the basis of obtained slurry seals we formed the samples of TLC models according to the procedure described in Subsection 2.2.4 and determined the speeds of cohesive strength gain after definite periods of time (Table 9).

Table 8

Optimum compositions of Slurry Seal according to the break criterion

\begin{tabular}{|c|c|c|c|c|c|c|}
\hline \multirow{2}{*}{$\begin{array}{c}\text { Slurry } \\
\text { Seal, No. }\end{array}$} & \multicolumn{5}{|c|}{ Components content, $\mathrm{g}$} & \multirow{2}{*}{ Break.time, s } \\
\hline & Granite scree & Portlandcement & Water & $\begin{array}{c}\text { Regulating } \\
\text { additive }\end{array}$ & $\begin{array}{l}\text { Bitumen } \\
\text { emulsion }\end{array}$ & \\
\hline \multicolumn{7}{|c|}{ BE 1} \\
\hline 1 & 100 & 1.25 & 10 & 2.00 & 14 & 206 \\
\hline \multicolumn{7}{|c|}{ BE 2} \\
\hline 2 & 100 & 1.25 & 10 & 2.25 & 14 & 180 \\
\hline \multicolumn{7}{|c|}{ BE 3} \\
\hline 3 & 100 & 1.00 & 10 & 0.50 & 14 & 190 \\
\hline
\end{tabular}

Table 9

Speeds of cohesive strength gain for the samples of Slurry Seal

\begin{tabular}{|c|c|c|c|c|c|}
\hline $\begin{array}{c}\text { Slurry } \\
\text { Seal, No. }\end{array}$ & Experiment time, hr & Destruction character & $M_{0}, \mathrm{H} \cdot \mathrm{m}$ & $\tau, \mathrm{MPa}$ & Mixture class \\
\hline \multirow{6}{*}{1} & 0.5 & Normal (N) & 1.2 & 0.252 & \multirow{6}{*}{$\begin{array}{l}\text { Quick-setting, slow self- } \\
\text { consolidation }\end{array}$} \\
\hline & 1.0 & Normal (N) & 1.2 & 0.252 & \\
\hline & 3.0 & Normal (N) & 1.3 & 0.273 & \\
\hline & 4.5 & Normal Spin (NS) & 2.0 & 0.42 & \\
\hline & 6.0 & Spin $(S)$ & 2.3 & 0.483 & \\
\hline & 7.0 & Solid Spin (SS) & 2.6 & 0.546 & \\
\hline \multirow{4}{*}{2} & 0.5 & Normal (N) & 1.2 & 0.252 & \multirow{4}{*}{$\begin{array}{l}\text { Quick-setting, quick self- } \\
\text { consolidation }\end{array}$} \\
\hline & 1.0 & Normal Spin (NS) & 2.1 & 0.441 & \\
\hline & 2.0 & Spin $(S)$ & 2.3 & 0.483 & \\
\hline & 3.0 & Solid Spin (SS) & 2.6 & 0.546 & \\
\hline \multirow{3}{*}{3} & 0.25 & Normal Spin (NS) & 2.1 & 0.441 & \multirow{3}{*}{$\begin{array}{l}\text { Super quick-setting, super } \\
\text { quick self-consolidation }\end{array}$} \\
\hline & 0.5 & $\operatorname{Spin}(\mathrm{S})$ & 2.4 & 0.504 & \\
\hline & 0.75 & Solid Spin (SS) & 2.7 & 0.567 & \\
\hline
\end{tabular}


The experimental results (Table 9, Fig. 4) show that the quickest gain in the mixture cohesion is observed during application of Nynas 70/100 bitumen (Slurry Seal No.3). In $15 \mathrm{~min}$ after TLC laying it is possible to open traffic with speed limit of $40 \mathrm{~km} / \mathrm{h}$ and after $45 \mathrm{~min}$ - without speed limit. The speed of cohesion strength gain of Slurry Seal based on oxidated BND 60/90 (Slurry Seal No.1) is unsatisfactory. The modification of the oxidated bitumen by ICR improves not only their adhesive properties but the speed of cohesive strength gain as well. Slurry Seal No.2 on the basis of BMP 60/90-52 exhibits high speeds of TLC structure formation. While using such coatings the traffic with speed limit of $40 \mathrm{~km} / \mathrm{h}$ is possible after $1 \mathrm{~h}$ after coating laying and after $3 \mathrm{~h}$ the traffic has no speed limits.

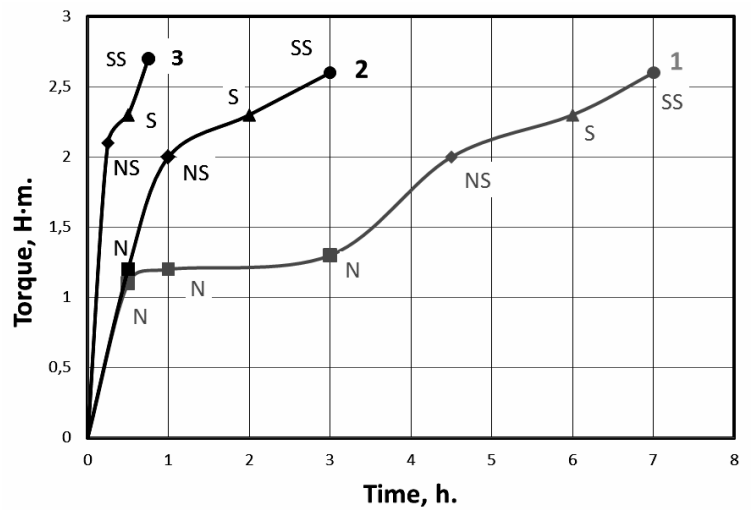

Fig. 4. Speed of cohesive strength gain for TLC based on Slurry Seals No. 1-3

\section{Conclusions}

1. To improve the adhesive properties of petroleum road bitumen considerably, including low-temperature adhesion, it is necessary to use indene-coumarine resin in the amount of 6-8 wt \% with the softening temperature of $403-413 \mathrm{~K}$.

2. The commercial emulsion of ECSM-60 type and Slurry Seal with the break time of $180 \mathrm{~s}$ are obtained on the basis of the oxidated bitumen and Redicote E-11 emulsifier. Both products meet the standards.

3. Slurry seals based on the petroleum bitumen modified by ICR have higher speeds of cohesive strength gain compared those obtained on the basis of the oxidated bitumen.

4. Modified bitumen may be used instead of deficient distillation bitumen for the production of thinlayer coatings from slurry seal.

\section{References}

[1] Virozhemsky V., Mishchenko M., Kushnir O. and Katukova V.: Avtoshlyahovyk Ukrainy, 2009, 1, 41.

[2] Savenko V., Ostroverhyi O. and Kaskiv V.: Avtoshlyahovyk Ukrainy, 2007, 1, 40.

[3] Klymchuk S.: Avtoshlyahovyk Ukrainy, 2003, 1, 31.
[4] Ukrainian standards VBN V.2.3-218-175-2002. Kyiv, Ukravtodor, 2002.

[5] Kishchynskyi S.: Dorozhnya Galyz Ukrainy, 2010, 253.

[6] Ayupov D., Potapova L., Murafa A. et al.: Stroitelnye Materialy, 2011, 15, 140.

[7] Zolotariov V. and Lapchenko A.: Avtoshlyahovyk Ukrainy, 2008, 5, 29.

[8] Al-Ameri M., Grynyshyn O. and Khlibyshyn Y.: Chem. \& Chem. Techn., 2013, 7, 323.

[9] Pushkariov Y. and Kunshenko B.: Trusy Odesskogo Polytechn. Univ., 2005, 23, 152.

[10] http://zkxychem.en.alibaba.com/productgrouplist219014637/

Coumarone_Resin.html.

[11] Pyshyev S., Grytsenko Y., Khlibyshyn Y. et al.: VostochnoEvrop. Zh. Pered. Techn., 2014, 64, 4.

[12] Pyshyev S., Nikulyshyn I., Grytsenko Y. and Gnativ Z.: UgleKhim. Zh., 2014, 5, 41.

[13] Sokolov V.: Inden-Kumaronovye Smoly. Metallurgiya, Moskwa 1978.

[14] Kolyandr L., Shustikov V., Andreeva V. et al.: A.c. 806691 SSSR, Publ. BI, 1981, 7.

[15] Ukrainian standards DSTU 4044-2001. Kyiv, Dergstandard, 2001.

[16] European standards EN 12591-2009.

[17] ISSA Technical Bulletin A105 (Revised). Annapolis, MD, May 2003.

[18] ISSA Technical Bulletin 139. Washington, DC, 1990.

[19] European standards EN 12274-4.

[20] Syrkin A. and Movsumzade E.: Osnovy Khimiyi Nefti i Gaza. UGNTKU, Ufa 2002.

[21] Rybak B.: Analiz Nefti i Nefteproduktov. GosNTI Neft. i gorno-toplivn. lit-ry, Moskwa 1962.

[22] European standards EN 1427 Bitumen and bituminous binders - Determination of softening point - Ring and Ball method.

[23] Odabashyan G. and Shvets V.: Laboraornyi Praktikum po Khimii i Technologii Organicheskogo i Neftekhimicheskogo Synteza. Khimiya, Moskwa 1992.

[24] Ukrainian standards DSTU B V.2.7-81-98.

[25] Pyshyev S., Grytsenko Y., Solodkyy S. and Sidun Y.: UgleKhim. Zh., 2015, 1, 36.

[26] Ukrainian standards DSTU B V.2.7-129:2013.

\section{ЗАСТОСУВАННЯ БІТУМНИХ ЕМУЛЬСІЙ НА ОСНОВІ ОКИСНЕНИХ, ДИСТИЛЯЩІЙНИХ I МОДИФІКОВАНИХ ОКИСНЕНИХ НАФТОВИХ БITУМІВ ДЛЯ ВИРОБНИЦТВА SLURRY SEAL}

Анотація. 3 нафтових бітумів, щзо відрізнялися способом виробництва (окисненого, залишкового, модифікованого окисненого), i емульгатора «Redicote E-11» одержано три товарних дорожніх емульсії, які надалі використано для приготування Slurry Seal та тонкомарових дорожніх покриттів (ТП) на їх основі. Показано переваги тонкошарових дорожсніх покриттів, у виробництві яких використовувався модифікований окиснений нафтовий бiтум, над тонкошаровими покриттями на основі окисненого бітуму та встановлено можливість заміни дороговартісного дистиляційного бітуму окисненим модифікованим бітумом для застосування в технологї Slurry Seal. 3апропоновано для модифікаиії окисненого бітуму використовувати інден-кумаронову смолу, щзо дає можливість суттєво покращити його адгезійні та когезійні властивості.

Ключові слова: лита емульсійно-мінеральна суміш, тонкошарові покриття, бітум, бітумні емульсіі, модифікатори, інден-кумаронова смола. 